\title{
Rasio Kesehatan dan Kinerja Bank Umum Berbasis Data Panel di Indonesiax
}

Handriko Anas ${ }^{1}$, Widarto Rachbini ${ }^{2}$

${ }^{1.2}$ Universitas Pancasila, Jl. Srengseng Sawah, Jagakarsa, Jakarta Selatan, 12640

INFO ARTIKEL

JEL Classsification:

G21

E50

Keywords:

net interest margin,

capital adequacy ratio,

efficiency ratio, loan to

deposit ratio, return on

asset, panel regression.

\begin{abstract}
A B S T RA K
Penelitian ini bertujuan menganalisis pengaruh kesehatan bank terhadap kinerja diukur dengan selama periode 2010-2014. Penelitian ini adalah penelitian kuantitatif dengan regresi data panel 96 bank umum di Indonesia. Hasil penelitian adalah rasio kecukupan modal, net interest margin, rasio efisiensi berpengaruh negatif terhadap return on asset. Rasio penyaluran kredit berpengaruh positif terhadap return on asset. Namun, rasio kredit bermasalah tidak mempengaruhi return on asset. Implikasi penelitian ini adalah dapat menjadi dasar bagi manajemen bank untuk membuat kebijakan merencanakan pengelolaan dana dan kredit guna meningkatkan return on asset.
\end{abstract}

\section{A B S T R A C T}

This study aims to analyze the influence of bank health on performance measured by during the period 2010-2014. This research is a quantitative research with regression of panel data of 96 commercial banks in Indonesia. The result of research is capital adequacy ratio, net profit margin, efficiency ratio have negative effect to return on asset. Loan disbursement ratio positively affects return on asset. However, the ratio of nonperforming loans does not affect return on assets. The implication of this research is that it can be the basis for bank management to make policy of fund and credit management to increase return on asset.

\section{Pendahuluan}

Krisis ekonomi akibat kegagalan kebijakan ekonomi makro, kegagalan regulasi dan kegagalan pasar mendorong kebijakan penilaian dan pemantauan ketahanan sistem keuangan dilakukan dengan dua pendekatan, yaitu makro prudensial adalah Bank Indonesia (BI) hanya menjalankan otoritas kebijakan moneter dan sistem pembayaran untuk menjaga stabilitas keuangan, salah satu adalah menjaga stabilitas nilai rupiah. Mikroprudensial adalah Otoritas Jasa Keuangan (OJK) melaksanakan pengawasan dan pembinaan bank. Fungsi BI sebagai lender of the last resort harus memiliki data yang mumpuni tentang sektor keuangan perbankan yang dipegang oleh OJK. BI dan OJK juga harus lebih kuat dalam mengawasi sistem keuangan Indonesia karena Industri perbankan adalah sektor penting pembangunan nasional sebagai financial intermediary dari pihakpihak yang memiliki dana lebih dengan pihak yang memerlukan dana. Beberapa faktor mempengaruhi profitabilitas bank bersumber dari indikator kinerja kesehatan seperti gambar 1 dan 2, diambil dan diolah dari data laporan Statistik Perbankan Indonesia dipublikasikan oleh Bank Indonesia tahun 2010 - 2015 yaitu permodalan (Capital Adequacy Ratio/ CAR), kualitas asset (Non-Performing Loan/

*Email Korespondensi: '1juang_82@yahoo.com, ${ }^{2}$ indotaxsolution@gmail.com 
$N P L$ ), Manajemen (Biaya Operasi disbanding Pendapatan Operasi/BOPO), likuiditas (Loan to Deposit Ratio/LDR) dan earning (Return On Assets /ROA dan Net Interest Margin/NIM).

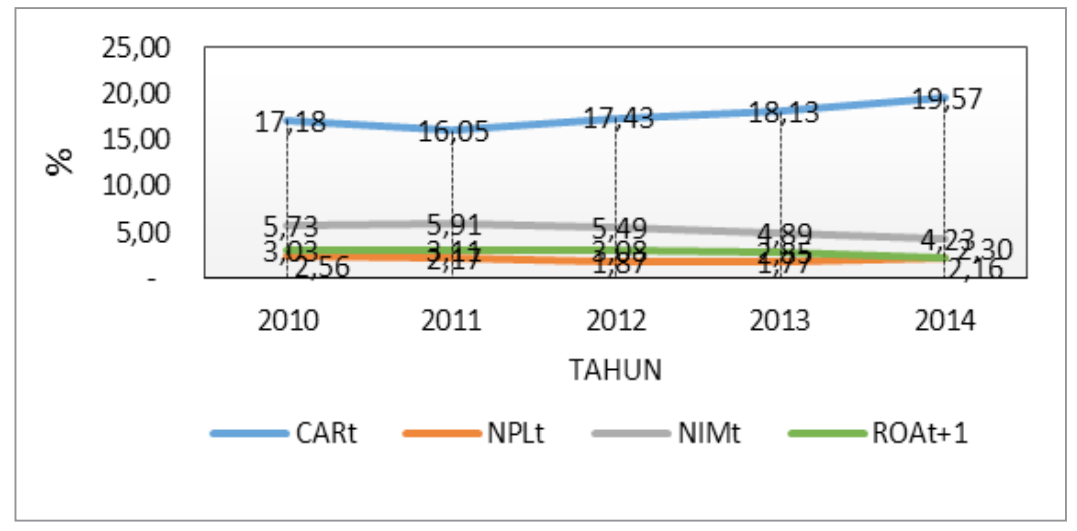

Sumber: Statistik Perbankan Indonesia - Bank Indonesia.

\section{Gambar 1. Perkembangan $\mathrm{CAR}_{t}, \mathrm{NPL}_{t}, \mathrm{NIM}_{t}$ dan $\mathrm{ROA}_{t+1}$}

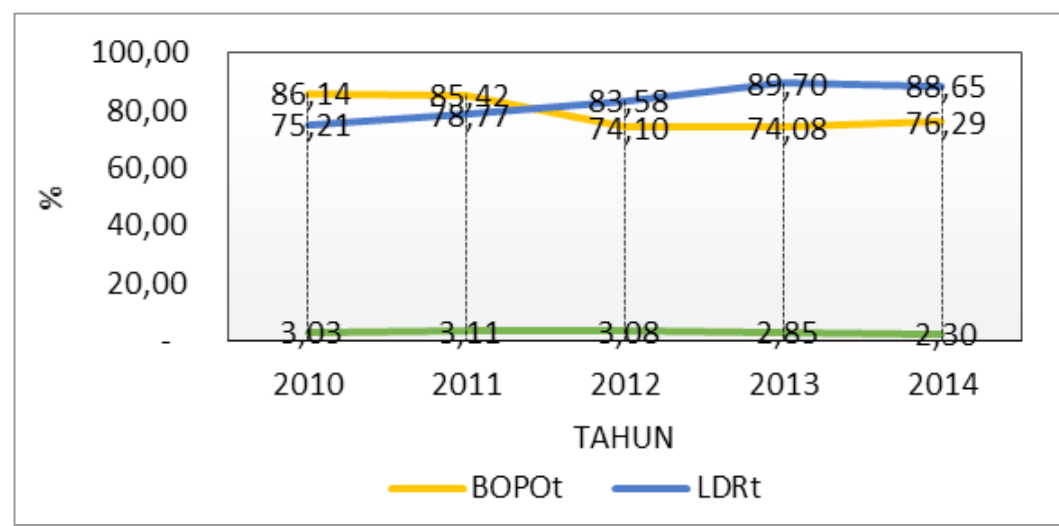

Sumber: Statistik Perbankan Indonesia - Bank Indonesia.

\section{Gambar 2. Perkembangan $\mathrm{BOPO}_{t}, \mathrm{LDR}_{t}$ dan $\mathrm{ROA}_{t+1}$}

Laporan Statistik Perbankan Indonesia tahun 2010 - 2015 menyatakan sejak tahun 2012 profitabilitas $\left(\mathrm{ROA}_{\mathrm{t}+1)}\right.$ Bank Umum mengalami perlambatan dari pertumbuhan laba tahun 2012. Tahun 2014 dan kuartal ke tiga 2015 pertumbuhan laba menurun drastic, NIM juga menurun pada tahun 2012, 2013 dan 2014, sempat naik di tahun 2011.

Dilihat dari indikasi kesehatan Bank Umum seperti ketahanan permodalan (CAR) dan fungsi intermediasi (LDR) mengalami peningkatan sejak tahun 2011 sampai tahun 2014, tren peningkatan LDR awal tahun 2010 sampai tahun 2013 dianggap aman bagi Bank Umum menjaga keseimbangan antara fungsi intermediasi dan kecukupan likuiditas berdasarkan PBI No. 15/7/ PBI/2013, namun sempat turun di tahun 2014 yang merupakan tahun politik di Indonesia adanya pemilihan umum dan pemilihan Presiden. Hal ini juga mempengaruhi NPL pada tahun 2014 mengalami kenaikan. Berdasarkan indikasi BOPO terlihat efisiensi Bank Umum menurun di tahun 2014.

Berdasarkan indikasi kesehatan Bank Umum seperti yang telah dijelaskan di atas selayaknya perbankan dapat memaksimalkan profitabilitas, namun sebaliknya profitabilitas perbankan menurun dan mengalami perlambatan. 


\section{Telaah Teori dan Pengembangan Hipotesis}

Indikasi kesehatan adalah aspek penting untuk diketahui oleh stakeholders. Melakukan penilaian kesehatan bank sangat berguna terhadap implementasi GCG (Good Corporate Governance) guna menghadapi risiko akan datang (PBI No.13/1/PBI/2011). Khususnya bagi para shareholders adanya penilaian tingkat kesehatan bank akan memberi sinyal dalam pengambilan keputusan investasi. Dalam melakukan penilian indikasi kesehatan bank, Bank Indonesia menggunakan faktor-faktor CAMEL, sebagai berikut (Siamat, 2004:209) yaitu permodalan, kualitas aset, manajemen, rentabilitas dan likuiditas.

\section{Pengaruh CAR terhadap ROA}

Nilai rasio CAR dipengaruhi oleh besarnya modal bank dan ATMR (Aset Tertimbang Menurut Risiko), juga dipengaruhi oleh pinjaman debitur. Tingginya CAR diakibatkan oleh penambahan modal atau penurunan ATMR. Penurunan ATMR diakibatkan oleh penurunan dana yang dipinjamkan kepada masyarakat. Penurunan pinjaman kepada masyarakat akan mengakibatkan penurunan income dan akun pinjaman dalam aktiva, akibatnya menurunkan nilai ROA. Beberapa peneliti sebelumnya yaitu Chandra (2013), Helhel (2014), Maheswari dan Sudirman (2015), Murti dan Aini (2014), Putranto, Herwany dan Sumirat (2012) dan Aftab, Samad dan Husain (2015) dalam penelitiannya menyimpulkan bahwa CAR berpengaruh signifikan negatif terhadap ROA.

$\mathrm{H}_{1}$ : CAR $\mathrm{C}_{\mathrm{t}}$ berpengaruh negatif terhadap $\mathrm{ROA}_{\mathrm{t}+1}$

\section{Pengaruh NPL terhadap ROA}

Nilai rasio NPL menunjukkan ketidakmampuan debitur membayar pinjaman atau terdapat kredit yang bermasalah maka debitur juga tidak memiliki kemampuan membayar bunga bank yang merupakan pendapatan utama perbankan akan ber-akibat ROA mengalami penurunan. Dari hasil penelitian Helhel (2014), Maheswari dan Sudirman (2015), Ngadlan dan Riadi (2010), Olweny dan Shipho (2011), Ongore dan Kusa (2013), Putranto, Herwany dan Sumirat (2012), Restiyana (2010), Setiyani dan Sudarsi (2013), Sudirman (2011), Tan Sau Eng (2013) dan Alper dan Anbar (2011) menyimpulkan bahwa NPL memiliki pengaruh yang negatif namun signifikan terhadap ROA. $\mathrm{H}_{2}: \mathrm{NPL}_{\mathrm{t}}$ berpengaruh negatif terhadap $\mathrm{ROA}_{\mathrm{t}+1}$

\section{Pengaruh NIM terhadap ROA}

Nilai rasio NIM adalah tingginya laba yang diperoleh bank dari dana yang dipinjamkan kepada masyarakat dan mengakibatkan nilai ROA mengalami peningkatan, hal ini dikarenakan rasio NIM dan ROA tersebut keduanya mengukur profitabilitas bank. Liu dan Pariyaprasert (2011), Maria (2015), Mitasari (2013), Nurmawati dan Widati (2012), Ngadlan dan Riadi (2010), Lantara (2012), Restiyana (2010), Setiawan (2015), Tan Sau Eng (2013) dari hasil penelitiannya menyimpulkan bahwa NIM berpengaruh signifikan dan secara positif mendorong peningkatan ROA.

$\mathrm{H}_{3}$ : $\mathrm{NIM}_{\mathrm{t}}$ berpengaruh positif terhadap $\mathrm{ROA}_{\mathrm{t}+1}$

\section{Pengaruh Rasio Biaya Operasional Pendapatan Operasional (BOPO) terhadap ROA}

BOPO mengambarkan besarnya pendapatan operasional guna dapat menutupi biaya operasional bank. Semakin besar biaya operasional bank akan berdampak pada penurunan income bank. Penurunan income bank mengakibatkan penurunan ROA. Artarina dan Masdjojo (2013), Chandra (2013), Defri (2012), Fatnanda dan Aini (2013), Lukitasari dan Kartika (2015), Maria (2015), Mitasari (2013), Menawati dan Indarti (2012, Maheswari dan Sudirman (2015), Musyarofatun (2013), Murti dan Aini (2014), Nurmawati dan Widati (2012), Olweny dan Shipho (2011), Purnamasari dan Hersugondo (2013), Pamulsari (2015), Prasanjaya dan Ramantha (2011), Porawouw, 
Pangemanan, dan Mekel (2014), Restiyana (2010), Rahayu dan Wahyu (2012), Sudiyatno dan Suroso (2010), Setiyani dan Sudarsi (2013), Shidieq dan Yuliandari (2012), Sukarno dan Syaichu (2006), Setiawan (2015), Sudirman (2011) menyimpulkan dalam penelitiannya bahwa BOPO berpengaruh negatif dan signifikan terhadap tingkat profitabilitas atau ROA) bank.

$\mathrm{H} 4: \mathrm{BOPO}_{\mathrm{t}}$ berpengaruh negatif terhadap $\mathrm{ROA}_{\mathrm{t}+1}$

\section{Pengaruh Loan to Deposit Ratio (LDR) terhadap ROA}

LDR adalah besarnya nilai loan atau pinjaman debitur dibandingkan dengan deposit atau dana yang dihimpun atau disimpan oleh masyarakat dalam bentuk deposito dan tabungan. Kredit yang diberikan kepada debitur individu atau korporasi adalah untuk menutupi cost of fund bank atau biaya bunga deposito dan bunga tabungan. Makin besar jumlah pinjaman yang diberikan oleh bank ke pada debitur maka interest income bank akan meningkat apabila persentase bunga pinjaman di atas bunga deposito dan tabungan, meningkatnya interest income bank akan memberikan pengaruh positif terhadaap ROA. Artarina dan Masdjojo (2013),
Alifa (2014), Chandra (2013), Indrawati dan Srimindarti (2013), Lukitasari dan Kartika (2015), Liu dan Pariyaprasert (2011), Mitasari (2013), Menawati dan Indarti (2012), Nurmawati dan Widati (2012), Narayana (2011), Putranto, Herwany dan Sumirat (2012), Prasanjaya dan Ramantha (2011), Porawouw, Pangemanan, dan Mekel (2014), Restiyana (2010), Setiyani dan Sudarsi (2013), Shidieq dan Yuliandari (2012), Sukarno dan Syaichu (2006), Setiawan (2015), Widati (2012), memberikan kesimpulan dari hasil penelitiannya bahwa Loan Deposit Ratio (LDR) berpengaruh positif signifikan terhadap ROA.

$\mathrm{H}$ 5: Variabel $\mathrm{LDR}_{\mathrm{t}}$ berpengaruh positif terhadap $\mathrm{ROA}_{\mathrm{t}+1}$

Penelitian terdahulu untuk pengaruh rasio CAR, LDR, NIM, NPL dan BOPO terhadap rasio ROA telah banyak dilakukan oleh penelitian sebelumnya. Namun, masih ditemukan inkonsistensi hasil penelitian dari ke 5 variabel yang diuji tersebut. Peneliti melakukan identifikasi kurang lebih 42 hasil penelitian disepanjang tahun 2006 sampai dengan tahun 2015, berbagai hasil penelitian terdahulu tersebut dapat digambarkan pada tebel 1 berikut:

Tabel 1. Hasil Penelitian Terdahulu

\begin{tabular}{lll}
\hline $\begin{array}{c}\text { Variabel } \\
\text { Independen }\end{array}$ & \multicolumn{1}{c}{ Signifikan } & \multicolumn{2}{c}{ Tidak Signifikan } \\
\hline CAR & Ozili (2015); Aftab, Samad dan Husain & Pamularsih (2015); Maria (2015); \\
& (2015); Helhel (2014); Maheswari dan & Lukitasari dan Kartika (2015); \\
& Sudirman (2014); Alifa (2014); Murti dan & Echekoba, Francis dan Kasie (2014); \\
& Nuraini (2014); Porawouw, Pangemanan & Tan Sau Eng (2013); Artarina dan \\
& dan Mekel (2014); Ongore dan Berhanukusa & Masidjojo (2013); Musyarofantun \\
& (2013); Setiawan (2013); Chandra (2013); & (2013); Mitasar (2013); Setiyani dan \\
& Widati (2012); Putranto, Herwany dan & sudarsi (2013); Fatnanda dan Nuraini \\
& Sumirat (2012); Sudirman (2011); Narayna & (2013); Purnamasari dan Hersugondo \\
& (2011); Olweny dan Shipho (2011); Liu & (2013); Indrawati dan Srimindarti \\
& dan Pariyaprasert (2011); Ngadlan dan & (2013); Karunia (2013); Lantara (2012); \\
& Riadi (2010); Sudiyatno dan Suroso (2010); Ashshidieq dan Sriyuliandari (2012); \\
& Restiyana (2010); Sukarno dan Syaichu & Defri (2012); Alper dan Anbar (2011); \\
(2006) & Prasanjaya dan Ramantha (2011) \\
\hline
\end{tabular}




\begin{tabular}{|c|c|c|}
\hline $\begin{array}{c}\text { Variabel } \\
\text { Independen }\end{array}$ & Signifikan & Tidak Signifikan \\
\hline NPL & $\begin{array}{l}\text { Pamularsih (2015); Helhel } \\
\text { Maheswari dan Sudirman (2014); } \\
\text { Porawouw, Pangemanan dan Mekel } \\
\text { (2014); Ongore dan Berhanukusa (2013); } \\
\text { Tan Sau Eng (2013); Setiawan (2013); } \\
\text { Mitasar (2013); sudarsi (2013); Putranto, } \\
\text { Herwany dan Sumirat (2012); Menawati } \\
\text { dan Indarti (2012); Alper dan Anbar (2011); } \\
\text { Sudirman (2011); Olweny dan Shipho } \\
\text { (2011); Liu dan Pariyaprasert (2011); } \\
\text { Ngadlan dan Riadi (2010); Restiyana } \\
\text { (2010); Banik dan Chandradas (2010) }\end{array}$ & $\begin{array}{l}\text { Maria (2015); Ozili (2015); Lukitasari } \\
\text { dan Kartika (2015); Alifa (2014); Murti } \\
\text { dan Nuraini (2014); Echekoba, Francis } \\
\text { dan Kasie (2014); Artarina dan Masidjojo } \\
\text { (2013); Musyarofantun (2013); Chandra } \\
\text { (2013); Fatnanda dan Nuraini (2013); } \\
\text { Purnamasari dan Hersugondo (2013); } \\
\text { Lantara (2012); Nurmawati dan Widati } \\
\text { (2012); Ashshidieq dan Sriyuliandari } \\
\text { (2012); Sukarno dan Syaichu (2006) }\end{array}$ \\
\hline LDR & $\begin{array}{l}\text { Pamularsih (2015); Lukitasari dan } \\
\text { Kartika (2015); Alifa (2014); Porawouw, } \\
\text { Pangemanan dan Mekel (2014); Setiawan } \\
\text { (2013); Artarina dan Masidjojo (2013); } \\
\text { Mitasari (2013); Chandra (2013); Indrawati } \\
\text { dan Srimindarti (2013); Widati (2012); } \\
\text { Putranto, Herwany dan Sumirat (2012); } \\
\text { Nurmawati dan Widati (2012); Menawati } \\
\text { dan Indarti (2012); Ashshidieq dan } \\
\text { Sriyuliandari (2012); Narayana (2011); } \\
\text { Prasanjaya dan Ramantha (2011); Liu dan } \\
\text { Pariyaprasert (2011); Restiyana (2010); } \\
\text { Sukarno dan Syaichu (2006) }\end{array}$ & $\begin{array}{l}\text { Maria (2015); Samad dan Husain } \\
\text { (2015); Murti dan Nuraini (2014); } \\
\text { Echekoba, Francis dan Kasie (2014); } \\
\text { Ongore dan Berhanukusa (2013); Tan } \\
\text { Sau Eng (2013); Musyarofantun (2013); } \\
\text { Setiyani dan Sudarsi (2013); Fatnanda } \\
\text { dan Nuraini (2013); Purnamasari dan } \\
\text { Hersugondo (2013); Rahayu dan Wahyu } \\
\text { (2012); Defri (2012); Ngadlan dan Riadi } \\
\text { (2010); Sudiyatno dan Suroso (2010); } \\
\text { Banik dan Chandradas (2010) }\end{array}$ \\
\hline ВOPO & $\begin{array}{l}\text { Pamulsari (2015); Maria (2015); Lukitasari } \\
\text { dan Kartika (2015); Maheswari dan } \\
\text { Sudirman (2014); Alifa (2014); Murti dan } \\
\text { Nuraini (2014); Porawouw, Pangemanan } \\
\text { dan Mekel (2014); Ongore dan Berhanukusa } \\
\text { (2013); Setiawan (2013); Artarina dan } \\
\text { Masidjojo (2013); Musyarofantun (2013); } \\
\text { Mitasari (2013); Chandra (2013); Setiyani } \\
\text { dan Sudarsi (2013); Fatnanda dan Nuraini } \\
\text { (2013); Purnamasari dan Hersugondo } \\
\text { (2013); Nurmawati dan Widati (2012); } \\
\text { Rahayu dan Wahyu (2012); Menawati dan } \\
\text { Indarti (2012); Ashshidieq dan Sriyuliandari } \\
\text { (2012); Defri (2012); Sudirman (2011); } \\
\text { Olweny dan Shipho (2011); Prasanjaya } \\
\text { dan Ramantha (2011); Ngadlan dan Riadi } \\
\text { (2010); Sudiyatno dan Suroso (2010); } \\
\text { Restiyana (2010); Sukarno dan Syaichu } \\
\text { (2006) }\end{array}$ & $\begin{array}{l}\text { Tan Sau Eng (2013); Widati (2012); Liu } \\
\text { dan Pariyaprasert (2011) }\end{array}$ \\
\hline NIM & $\begin{array}{l}\text { Maria (2015); Tan Sau Eng (2013); Setiawan } \\
\text { (2013); Mitasari (2013); Lantara (2012); } \\
\text { Nurmawati dan Widati (2012); Liu dan } \\
\text { Parayaprasert (2011); Ngadlan dan Riadi } \\
\text { (2010); Restiyana (2010) }\end{array}$ & $\begin{array}{l}\text { Pamulsari (2015); Alper dan Anbar } \\
\text { (2011); }\end{array}$ \\
\hline
\end{tabular}




\section{Metode}

Penelitian ini menggunakan metoda purposive sampling. Kriteria yang dipakai adalah sebagai berikut:

1. Bank Umum selama 5 periode yaitu tahun 2010 sampai dengan 2014 untuk CAR, NPL, NIM, BOPO dan LDR, untuk ROA tahun 2011 sampai dengan kuartal tiga 2015. Data diperoleh dari laporan publikasi rasio keuangan Bank Umum di laman Otoritas Jasa Keuangan (OJK).

2. Data yang tercakup dalam penelitian ini adalah 96 Bank Umum di Indonesia, 96 Bank Umum tersebut adalah Bank Persero, Bank Pembangunan Daerah, Bank Umum Swasta Nasional Devisa, Bank Non Devisa, Bank Campuran (joint venture) dan Bank Asing. Tidak termasuk Bank Syariah dan Bank Perkreditan Rakyat (lihat lampiran 1).

Penelitian ini menggunakan metode statistik berbentuk model regresi linier berganda. Dengan persamaan regresi sebagai berikut:

$$
\begin{aligned}
Y_{\mathrm{it}+1}= & \alpha+\beta_{1} \mathrm{CAR}_{\mathrm{it}}+\beta_{2} \mathrm{NPL}_{\mathrm{it}}+\beta_{3} \mathrm{NIM}_{\mathrm{it}} \\
& +\beta_{4} \mathrm{BOPO}_{\mathrm{it}}+\beta_{5} \mathrm{LDR}_{\mathrm{it}}+\varepsilon_{\mathrm{it}}
\end{aligned}
$$

Dimana :

$\mathrm{Y}_{\mathrm{it}+1} \quad$ : Kinerja perbankan yang diukur dengan ROA $_{t+1}$

$\alpha \quad$ : Konstanta

CAR $_{\text {it }} \quad$ : Capital Adequacy Ratio

$\mathrm{NPL}_{\text {it }}$ : Non Performing Loan

$\mathrm{NIM}_{\text {it }} \quad$ : Net Interest Margin

BOPO $_{\text {it: }}$ : Biaya Operasional Pendapatan Operasional

$\mathrm{LDR}_{\text {it }} \quad$ : Loan to Deposit Ratio

$\varepsilon_{\text {it }} \quad:$ error

Besarnya konstanta tercermin dari " $\alpha$ "dan besarnya koefisien regresi dari masing-masing variabel independen ditunjukan dengan $\beta_{1}, \beta_{2}$, $\beta_{3}, \beta_{4}$ dan $\beta_{5}$.

Analisis data menggunakan teknik regresi data panel dengan bantuan aplikasi Eviews versi 9. Regresi data panel yang diteliti berdasarkan data setiap Bank Umum guna menguji pengaruh variabel-variabel penentu $\left(\mathrm{CAR}_{\mathrm{t}}, \mathrm{NPL}_{\mathrm{t}}, \mathrm{NPM}_{\mathrm{t}}\right.$,
$\mathrm{BOPO}_{\mathrm{t}}$, dan $\mathrm{LDR}_{\mathrm{t}}$ ) terhadap $\mathrm{ROA}_{\mathrm{t}+1}$ satu tahun ke depan. Tahapan pengujian dilakukan dengan cara sebagai berikut:

1. Analisa Deskriptif: Melakukan perhitungan rata-rata, median, data maksimum, data minimum, dan standar deviasi terhadap data yang dikumpulkan didalam penelitian ini. Tujuan analisa deskriptif adalah guna melihat kewajaran dan karakteristik dari masing-masing variabel.

2. Menentukan Model Terbaik: Pemilihan model terbaik dari regresi data panel adalah dengan melakukan pengujian sebagai berikut:

- Uji Chow yaitu membandingkan Pooled Least Square dengan Fixed Effect

Hasil output aplikasi eviews untuk estimasi berdasarkan metode fixed effect dan pooled least square dapat dilakukan membandingkan nilai $\mathrm{F}$ statistik dengan $\mathrm{F}$ table, jika F statistik $>$ F Tabel maka metode fixed effect lebih baik.

- Uji Hausmen yaitu membandingkan Fxed Effect dengan Random Effect

Membandingkan output aplikasi eviews untuk estimasi berdasarkan metode fixed effect dan metode random effect dapat dilakukan uji Hausman. Jika nilai Hausman (Chi-Squre Statistic) yang dihasilkan lebih besar dai nilai Chi - square hitung maka metode fixed effect lebih baik dari pada random effect.

3. Melakukan uji asumsi klasik terdiri dari uji autokorelasi, multikolinearitas, dan heteroskedastisitas.

4. Melakukan Uji t-statistik

5. Menginterpreasikan nilai koefisien determinasi $\left(\mathrm{R}^{2}\right)$ untuk mengukur kemampuan variabel independen $\left(\mathrm{CAR}_{\mathrm{t}}, \mathrm{LDR}_{\mathrm{t}}, \mathrm{NIM}_{\mathrm{t}}\right.$, $\mathrm{NPL}_{t}, \mathrm{BOPO}_{\mathrm{t}}$ ) guna menjelaskan variabel dependen $\left(\mathrm{ROA}_{t+1}\right)$ dan dapat dijadikan acuan apabila model baik (goodness of fit). Nilai koefisien determinasi yaitu 
antara nol dan satu. Nilai $\mathrm{R}^{2}$ yang kecil memiliki arti kemampuan variabelvariabel independen dalam menjelaskan variasi variabel dependen sangat terbatas. Nilai $\mathrm{R}^{2}$ mendekati satu berarti variabelvariabel independen memberikan hampir semua informasi yang dibutuhkan untuk memprediksi variasi variabel dependen.

\section{Hasil Penelitian dan Pembahasan}

Hasil penelitian menjelaskan analisis atas estimasi pengaruh kesehatan bank $\left(\mathrm{CAR}_{\mathrm{t}}, \mathrm{NPL}_{\mathrm{t}}\right.$,
$\mathrm{NIM}_{\mathrm{t}}, \mathrm{COPO}_{\mathrm{t}}$ dan $\mathrm{LDR}_{\mathrm{t}}$ ) periode $2010-2014$ terhadap Return on Asset $\left(\mathrm{ROA}_{\mathrm{t}+1}\right)$ periode 2011 - kuartal tiga 2015 dari 96 Bank Umum. Statistik deskriptif terdiri dari penghitungan mean, median, standar deviasi, maksimum, dan minimum dari masing-masing data sampel. Analisis ini dimaksudkan guna memberikan gambaran distribusi dan perilaku data sampel. Dengan melihat probability atas Jarque-Bera dan tingkat signifikansi 95\% (alfa $=5 \%$ ) dapat disimpulkan bahwa variabel $\mathrm{CAR}_{t}, \mathrm{NPL}_{\mathrm{t}}$, $\mathrm{NIM}_{\mathrm{t}}, \mathrm{BOPO}_{\mathrm{t}}, \mathrm{LDR}_{\mathrm{t}}$ dan variabel $\mathrm{ROA}_{\mathrm{t}+1}$ telah terdistribusi secara normal.

Table 2. Statistik Deskriptif Variabel $\mathrm{ROA}_{\mathrm{t}+1}$

\begin{tabular}{|c|c|c|c|c|c|c|}
\hline Statistik Deskriptif & ROA & CAR & NPL & NIM & BOPO & LDR \\
\hline Mean & 2.236094 & 21.03195 & 2.288568 & 6.240703 & 80.48091 & 95.16352 \\
\hline Median & 2.170000 & 17.00000 & 1.740000 & 5.575000 & 80.76000 & 84.93500 \\
\hline Maximum & 7.440000 & 146.2500 & 51.00000 & 21.22000 & 173.8000 & 620.2500 \\
\hline Minimum & -7.580000 & 9.000000 & 0.030000 & -6.250000 & 30.18000 & 40.22000 \\
\hline Jarque-Bera & 479.0547 & 13949.07 & 267273.0 & 315.0003 & 955.7755 & 22163.99 \\
\hline Probability & 0.000000 & 0.000000 & 0.000000 & 0.000000 & 0.000000 & 0.000000 \\
\hline Observations & 384 & 384 & 384 & 384 & 384 & 384 \\
\hline Cross sections & 96 & 96 & 96 & 96 & 96 & 96 \\
\hline
\end{tabular}

Sumber: Hasil olahan data panel eviews versi 9

Pemilihan pendekatan pooled least square atau fixed effect. Sum Square Residual hasil ouput aplikasi eviews untuk estimasi metode fixed effect dan pooled least square sebagaimana tergambar pada Tabel 3, dapat dilakukan membandingkan nilai $\mathrm{F}$ statistik dengan $\mathrm{F}$ tabel, sebagai berikut:

Table 3. Dasar Perhitungan Pemilihan Pendekatan Pooled Least Square atau Fixed Effect

\begin{tabular}{llcc}
\hline Notasi & \multicolumn{2}{c}{ Uraian } & Nilai \\
\hline SSR1 & $\begin{array}{l}\text { Sum Square Residual } \\
\text { Pooled Least Square }\end{array}$ & $4,251,059$ \\
SSR2 & $\begin{array}{l}\text { Sum Square Residual } \\
\text { Fixed Effect }\end{array}$ & $1,897,396$ \\
$\mathrm{~N}$ & $\begin{array}{l}\text { Banyaknya cross section } \\
\mathrm{T}\end{array}$ & 96 \\
$\mathrm{~K}$ & $\begin{array}{l}\text { Banyaknya series } \\
\text { Banyaknya variabel } \\
\text { bebas }\end{array}$ & 4 \\
\hline
\end{tabular}

a. Menghitung nilai F Statistik

$$
\begin{aligned}
& \frac{(\mathrm{SSR} 1-\mathrm{SSR} 2)}{\mathrm{N}-1} \\
& \begin{array}{c}
\text { F Statistik }= \\
\frac{\mathrm{SSR} 2}{\mathrm{NT}-\mathrm{N}-\mathrm{k}}
\end{array}=\frac{(425,1059-189,7396)}{96-1} \\
& \frac{189,7396}{96 \times 4-96-5}
\end{aligned}
$$

b. Mendapatkan nilai F Tabel

Nilai $\mathrm{F}$ berdasarkan Tabel Distribusi $\mathrm{F}$ dengan probabilitas $\alpha=10 \%$, dof1 $=$ N- 1= 96 dan dof $2=$ NT-N-k = 293 yang didapatkan dengan bantuan aplikasi microsoft excel adalah sebesar 1,22788876

c. Membandingkan nilai $\mathrm{F}$ statistik dengan $\mathrm{F}$ Tabel

Dengan nilai F Statitik sebesar 3.8259 dan F Tabel sebesar 1,22788876 maka F statistik > F Tabel sehingga metode fixed effect lebih baik. 
Pemilihan pendekatan fixed effect atau random effect (uji Hausman). Uji Hausman dilakukan dengan bantuan aplikasi eviews menghasilkan Nilai Hausman (Chi-Squre Statistic) sebesar 118,694893 dan nilai Chi square dengan probabilitas $\alpha=10 \%$ dan dof $=\mathrm{k}=$ 5 didapatkan dengan bantuan aplikasi Microsoft Excel adalah sebesar 9,23635690. Dengan ChiSqure Statistic > Chi-Square aplikasi Microsoft Excel maka metode fixed effect lebih baik dari pada random effect.

Pelanggaran asumsi heterokedastisitas sering terjadi pada data cross-section dan sangat jarang terjadi pada data time series (Agus, 2007:126). Model regresi data panel ini dibangun dengan bantuan aplikasi eviews versi 9 yang telah menyediakan menu Cross-section weights, menegaskan bahwa pelanggaran asumsi heterokedastisitas telah dipertimbangkan dalam model. Analisis Pelanggaran Asumsi Autokorelasi yaitu dengan melakukan deteksi adanya autokorelasi adalah dengan metode Durbin - Watson. Hail Output nilai statistik Durbin - Watson (d) aplikasi Eviews metode fixed effect sebesar 2,331277, jika nilai sample 96 dan 5 variabel independen maka berdasarkan tabel DW didapatkan nilai du 1,6298 $(\alpha=1 \%)$ maka 4-du adalah 2.3702, dapat disimpulkan tidak terjadi autokorelasi. Untuk mendeteksi dapat multikolinieritas dilakukan dengan melihat koefisien determinasi dan banyaknya variabel independen yang siginifikan mempengaruhi variabel independen. Menurut Murhadi (2011:18) untuk mengatasi multikolinieritas dilakukan kombinasi data crosssectional dan data time-series yang disebut dengan data panel (pooling the data), sehingga dapat disimpulkan tidak dibutuhkan uji multikolinearitas.

Koefisien determinasi model ditunjukkan dengan nilai Adjusted $R^{2}$ sebesar 0,954920. Nilai probablity $\mathrm{F}$ (F-statistic) hasil output aplikasi eviews adalah 0,0000 berarti variabel independen secara bersama - sama dan signifikan mempengaruhi variabel dependen. Banyaknya variabel independen yang siginifikan yaitu dengan membandingkan nilai probablity pada output aplikasi eviews sebagaimana tergambar pada Tabel 4 dengan $\alpha=10 \%$ :

Tabel 4. Perbandingan nilai probablity pada output aplikasi eviews dengan $\alpha=10 \%$ terhadap variabel bebas $\mathrm{ROA}_{t+1}$

\begin{tabular}{llll}
\hline \multicolumn{1}{c}{ Variabel } & Notasi & Prob. & \multicolumn{1}{c}{ Signifikasi dengan $\boldsymbol{\alpha}=\mathbf{0 . 1}$} \\
\hline Capital Adequte Ratio & $\mathrm{CAR}_{\mathrm{t}}$ & 0.0012 & Signifikan $\left(\mathrm{H}_{1} 1\right.$ diterima $)$ \\
Non Performing Loan & $\mathrm{NPL}_{\mathrm{t}}$ & 0.2591 & Tidak signifikan $\left(\mathrm{H}_{0} 2\right.$ diterima $)$ \\
Net Interest Margin & $\mathrm{NIM}_{\mathrm{t}}$ & 0.0623 & Signifikan $\left(\mathrm{H}_{1} 3\right.$ diterima $)$ \\
Biaya Operasional Pendapatan Operasional & $\mathrm{BOPO}_{\mathrm{t}}$ & 0.0219 & Signifikan $\left(\mathrm{H}_{1} 4\right.$ diterima $)$ \\
Loan to Deposit Ratio & $\mathrm{LDR}_{\mathrm{t}}$ & 0.0491 & Signifikan $\left(\mathrm{H}_{1} 5\right.$ diterima $)$ \\
\hline
\end{tabular}

Dari hasil regresi data panel model fixed effect dengan Cross-section weights didapatkan 4 variabel signifikan yaitu $\mathrm{CAR}_{t}, \mathrm{NIM}_{\mathrm{t}}, \mathrm{BOPO}_{\mathrm{t}}$ dan $\mathrm{LDR}_{\mathrm{t}}$ yang mempengaruhi $\mathrm{ROA}_{\mathrm{t}+1}$. Kondisi ini menunjukkan tidak terjadi multikolinieritas.

\section{Pengaruh CAR terhadap ROA}

Nilai koefisien $\mathrm{CAR}_{\mathrm{t}}-0.008154$ memberikan arti semakin turun nilai $\mathrm{CAR}_{\mathrm{t}}$ suatu Bank Umum dapat menaikan profitabilitas atau $\mathrm{ROA}_{\mathrm{t}+1}$ satu tahun kedepan Bank Umum di Indonesia. Rasio ini merupakan rasio permodalan bank. Seperti telah ditentukan oleh Bank Indonesia yang berlandaskan kepada Bassel, nilai CAR harus berada di atas $8 \%$ atau minimum sebesar $8 \%$ yang berfungsi sebagai penyangga risiko kredit. Apabila CAR rendah, bank diharuskan untuk meningkatkannya seperti tambahan modal disetor. Tingginya nilai CAR dapat diakibatkan oleh penambahan modal atau penurunan 
ATMR (Aset Tertimbanng Menurut Risiko). Dengan asumsi tidak ada penambahan modal dan terjadinya penurunan ATMR diakibatkan oleh penurunan dana yang dipinjamkan kepada masyarakat akan mengakibatkan penurunan income dan akun pinjaman dalam aktiva, sehingga akan berimbas penurunan nilai ROA satu tahun ke depan, hasil penelitian ini juga sesuai dengan hasil laporan Statistik Perbankan Indonesia yang dipublikasikan oleh Bank Indonesia (Gambar 1) yaitu kenaikan nilai rasio CAR akan mempengaruhi penurunan ROA satu tahun kedepan, artinya di periode tahun 2011 sampai dengan 2014 adanya penambahan modal atau penurunan ATMR atau dana yang dipinjamkan ke masyarakat oleh Bank Umum di Indonesia. Terutama tahun sebelum dan sesudah di tahun 2014 penurunan ATMR sangat signifikan dikarenakan tahun politik di Indonesia sehingga akan berimbas terhadap penurunan $\mathrm{ROA}_{\mathrm{t}+1}$ sampai dengan kuartal ke tiga tahun 2015, Bank Umum lebih ketat dan berhati-hati dalam menyalurkan kredit ke pihak ketiga. Pihak manajemen bank perlu untuk memerhatikan besaran CAR yang ideal yaitu berkisar $8 \%$, jangan terlalu tinggi karena akan meningkatkan dana idle yang akan berimbas pada penurunan $\mathrm{ROA}_{\mathrm{t}+1}$ yaitu kurangnya pemasukan dari bunga kredit dan adanya kewajiban bank membayar bunga Dana Pihak Ketiga (DPK). CAR juga tidak terlalu rendah karena bank akan kehilangan kepercayaan dari masyarakat sehingga berakibat DPK akan mengalami penurunan.

\section{Pengaruh NIM terhadap ROA}

Nilai koefisien NIM -0.031129 menunjukan semakin besar nilai NIM $_{t}$ suatu Bank Umum memberikan pengaruh penurunan $\mathrm{ROA}_{\mathrm{t}+1}$ untuk satu tahun ke depan. Rasio NIM dihasilkan dari akun pendapatan dan beban bunga dalam laporan laba rugi dan saldo laba. Namun, berdasarkan laporan Statistik Perbankan Indonesia (Gambar 1) menunjukan penurunan rasio NIM $_{t}$ diikuti rasio $\mathrm{ROA}_{\mathrm{t}+1}$ yang stabil dikarenakan Bank Umum sudah melakukan antisipasi terhadap keluarnya kebijakan BI yaitu NIM akan menjadi sebagai indikator efisiensi, menurut Sutaryono (2013) BI justru akan menekan NIM Bank Umum agar semakin rendah mendekati NIM bank-bank Malaysia, Filipina dan Thailand yang berada sekitar 2-3\%. Dengan memanfaatkan suku bunga dasar kredit (SBDK) akan lebih baik kalau penurunan NIM dilakukan melalui penurunan SBDK. Hal ini juga terkait dengan aturan baru yang mewajibkan Bank Umum untuk mengucurkan kredit UMKM minimal 20\% dari kredit produktif (kredit modal kerja dan kredit investasi) atau kredit UKM minimal $10 \%$ dari total portofolio kredit. Dengan demikian, Bank Umum akan memperoleh insentif menambah jaringan kantor. Akibat logisnya, semua Bank Umum akan berlombalomba menyalurkan kredit ke segmen tersebut untuk meraih target minimal 20\%. Adanya SBDK kredit mikro secara bertahap akan menurunkan suku bunga kredit mikro. Susuai dengan Surat Edaran Nomor 15/1/DPNP tanggal 15 Januari 2013 tentang Transparansi SBDK, BI menetapkan SBDK untuk kredit mikro yang sebelumnya hanya untuk kredit korporasi, kredit ritel, kredit konsumsi (KPR dan non-KPR), tujuannya adalah guna menurunkan suku bunga kredit mikro yang masih tinggi sekitar 30\%. Dengan demikian penurunan rasio NIM Bank Umum guna memperoleh insentif tambahan dalam menambah jaringan kantor atau ekpansi, oleh karena itu Bank Umum sudah melakukan antisipasi atau strategi sehingga penurunan $\mathrm{NIM}_{t}$ yang seharusnya memberikan pengaruh terhadap penurunan $\mathrm{ROA}_{\mathrm{t}+1}$ tidak terbukti didalam penelitian ini, sebaliknya penurunan $\mathrm{NIM}_{t}$ secara signifikan akan menaikan $\mathrm{ROA}_{t+1}$ dikarenakan kebijakan pemerintah seperti tersebut di atas yaitu dengan penurunan NIM Bank Umum akan mendapatkan insentif dalam bentuk ekspansi pembukaan cabang baru dan penyaluran kredit UMKM sebesar $20 \%$ yang akhirnya akan meningkatkan $\mathrm{ROA}_{\mathrm{t}+1}$ Bank Umum di tahun berikutnya. 


\section{Pengaruh BOPO terhadap ROA}

Nilai koefisien $\quad \mathrm{BOPO}_{\mathrm{t}}-0.010855$ menunjukan semakin turun nilai $\mathrm{BOPO}_{\mathrm{t}}$ suatu bank maka dapat menaikan profitabilitas atau $\mathrm{ROA}_{\mathrm{t}+1}$ untuk satu tahun kedepan Bank Umum di Indonesia. Artinya pencapaian tingkat efisiensi Bank Umum antara lain diukur melalui semakin efisiensi bank dalam mengelola biaya dan pendapatannya. Sesuai Gambar 2 yaitu menurut Statistik Perbankan Indonesia yang dipublikasikan oleh Bank Indonesia menegaskan bahwa seluruh kelompok Bank Umum telah mengantongi rasio BOPO ideal yaitu berkisar antara $70 \%-80 \%$. Namun, BI akan terus menekan BOPO agar lebih rendah lagi menjadi $60 \%-70 \%$. Hal ini bertujuan untuk mendekati BOPO bank-bank Asia Tenggara yang mencapai 40\%-60\%. Pada tanggal 27 Desember 2012, BI telah menerbitkan Peraturan Bank Indonesia Nomor 14/26/PBI/2012 secara garis besar Bank Indonesia menetapkan ekspansi atau pembukaan kantor baru akan dikaitkan dengan modal inti dan tingkat efisiensi bank atau ekspansi tidak semudah seperti selama ini.

\section{Pengaruh LDR terhadap ROA}

Nilai koofisien $\mathrm{LDR}_{\mathrm{t}} 0.002970$ menunjukan signifikan positif mempengaruhi $\mathrm{ROA}_{\mathrm{t}+1}$ satu tahun kedepan Bank Umum di Indonesia. Karena Dana Pihak Ketiga (DPK) yang dihimpun oleh Bank Umum akan disalurkan kembali dalam bentuk kredit ke Nasabah, di sini Bank memiliki keuntungan dengan adanya selisih suku bunga antara kewajiban yang harus dibayarkan ke dana pihak ketiga (mencakup giro, tabungan dan deposito dalam rupiah dan valuta asing) dengan suku bunga yang dihasilkan dari pemberian kredit kepada pihak ketiga dalam rupiah dan valuta asing (tidak termasuk kredit kepada bank lain). Keuntungan ini akan dibukukan pada laporan laba rugi dan saldo laba. Hal ini juga akan mengakibatkan $\mathrm{ROA}_{\mathrm{t}+1}$ Bank Umum mengalami kenaikan.

\section{Pengaruh NPL terhadap ROA}

Rasio NPL $\mathrm{t}_{\mathrm{t}}$, tidak signifikan mempengaruhi profitabilitas atau $\mathrm{ROA}_{\mathrm{t}+1}$ untuk satu tahun kedepan Bank Umum di Indonesia. Ketahanan modal yang dimiliki Bank Umum terus meningkat (Gambar 1) maka kenaikan NPL memaksa bank untuk membentuk cadangan kerugian penurunan nilai (CKPN) sesuai dengan PSAK, dengan membentuk CKPN Bank Umum masih dapat mengeliminasi kredit bermasalah sehingga laba bank atau $\mathrm{ROA}_{\mathrm{t}+1}$ tidak terpengaruh dengan NPL yang tinggi, selain itu Bank Umum masih dapat memperoleh sumber laba dari sumber lain seperti fee based income yang juga memberikan pengaruh yang relative tinggi terhadap tingkat $\mathrm{ROA}_{\mathrm{t}+1}$.

\section{Simpulan, Keterbatasan dan Implikasi Hasil Penelitian}

Berdasarkan Dari hasil pengujian yang dilakukan dengan model regresi data panel terhadap 96 Bank Umum di Indonesia untuk periode 2010 - 2014 ditemukan bukti empiris bahwa Capital Adequacy Ratio $\left(\mathrm{CAR}_{\mathrm{t}}\right)$, Net Interest Margin (NIM) dan Biaya Operasional dan Pendapatan Operasional $\left(\mathrm{BOPO}_{\mathrm{t}}\right)$ berpengaruh negatif terhadap Profitabilitas. Non Performing Loan (NPL $\mathrm{t}_{\mathrm{t}}$ tidak berpengaruh terhadap Profitabilitas sedangkan Loan to Deposit Ratio (LDR $)$ berpengaruh positif terhadap Profitabilitas $\left(\mathrm{ROA}_{\mathrm{t}+1}\right)$ untuk satu tahun kedepan pada Bank Umum di Indonesia. Hasil penelitian mencerminkan bahwa Bank Umum tergolong baik dan mampu mengatasi pengaruh negatif kondisi perekonomian dan industri keuangan.

Penelitian ini diharapkan dapat berkontribusi terhadap penelitian lebih lanjut mengenai tingkat kesehatan bank. Simpulan hasil penelitian inijuga diharapkan berkontribusi dalam meyakinkan para manajemen Bank Umum mengenai pentingnya untuk menjaga kesehatan bank dan tidak semata-mata mengejar keuntungan yang tinggi, juga bank memiliki kontribusi tehadap 
seluruh masyarakat Indonesia terutama sektor mikro. Kelebihan penelitian ini adalah model yang terbangun telah memerhatikan estimasi profit pada tahun berikutnya dan model regresi panel menyediakan data yang lebih banyak dan informasi yang lebih lengkap serta bervariasi. Dengan demikian akan dihasilkan degress of freedom (derajat bebas) yang lebih besar dan mampu meningkatkan presisi dari estimasi yang dilakukan. Adapun kelemahan penelitian ini antara lain belum mencakup faktor-faktor penilaian tingkat kesehatan bank meliputi: profil risiko, Good Corporate Governance (GCG), pelayanan Bank Umum memenuhi harapan masyarakat dan brand awareness, serta kualitas dan kompetensi sumber daya manusia.

Saran bagi peneliti selanjutnya dan akademisi, perlunya meneliti variabel-bariabel kesehatan Bank Umum yang diduga dapat mempengaruhi kinerja bank seperti profil risiko, Good Corporate Governance (GCG), pelayanan Bank Umum, kualitas dan kompetensi sumber daya manusia. Membandingkan pengaruh tingkat kesehatan Bank Umum terhadap ROA dan $\mathrm{ROA}_{\mathrm{t}+1}$. Hasil penelitian ini dapat dijadikan sebagai rujukan atau dasar merencanakan pengelolaan dana dan kredit guna meningkatkan Return on asset (ROA) satu tahun kedepan. Dasar kebijakannya dengan melihat pengaruh variabel independenpen terhadap ROA untuk tahun berikutnya.

\section{Daftar Referensi}

Al-Tamimi, H.A., Hassan and Jabnoun, N, 2006. Service Quality and Bank Performance: A Comparison of the UAE National and Foreign Bank, Journal of Finance India Vol XX No.1 March 2006. http://www. proquest.com/pqdweb

Alper, D, dan Anbar, A, 2011. Bank Specific and

Macroeconomic Determinants of Commercial Bank Profitability: Empirical Evidence From Turkey (hal. 10-13), Volume 2, Number 2, 2011, pp. 139-152,
ISSN: 1309-2448, Business and Economics Research Journal. www.berjournal.com.

Aftab, N, Samad, N, dan Husain, T, 2015. Historical Analysis of Bank Profitability Using CAMEL Parameters: Role of Ownership and Political Regimes in Pakistan (hal. 151),Vol. 7, No. 2, 2015, ISSN 1916-971X E-ISSN 1916-9728, International Journal of Economics and Finance. Published by Canadian Center of Science and Education.

Artarina, O, dan Masdjojo, G.N., 2013. FaktorFaktor Yang Mempengaruhi Rentabilitas Pada BPR di Kabupaten Blora (hal. 49-50), Vol 2, No.1, 2013, Dinamika Akuntansi Keuangan dan Perbankan.

http://www.unisbank.ac.id/ojs/index.php/fe9/ article/view/2106.

Agus, W, 2007: Teori dan Aplikasi untuk Ekonomi dan Bisnis. Ekonosia, FEUII Yogya.

Alifa, Y.B., 2014. Pengaruh CAR, NPL, BOPO, dan LDR Terhadap Profitabilitas Bank (ROA), Pada Perusahaan Perbankan Yang Terdaftar di Bursa Efek Indonesia Periode 2009-2012 (hal. 87-91), Vol.3 Edisi III, Jurnal Manajemen Bisnis Indonesia. http://journal.student.uny.ac.id/jurnal/ artikel/7524/50/737.

Bank Indonesia, 2015. Statistik Perbankan Indonesia.

http://www.bi.go.id/id/statistik/perbankan/ indonesia/Default.aspx

Bank Indonesia, 2011. Peraturan bank Indonesia No.13/1/PBI/2011. http//www.bi.go.id

Bank Indonesia, 2011. Peraturan bank Indonesia No. 15/7/PBI/2013. http//www.bi.go.id

Bank Indonesia, 2011. Peraturan bank Indonesia No. 14/26/PBI/2012. http//www.bi.go.id

Bank Indonesia, 2013. Transparansi SBDK, Surat Edaran No. 15/1/DPNP. http//www. bi.go.id

Bank Indonesia, 2014. Kajian Stabilitas Keuangan (No.23, September 2014). http// www.bi.go.id 
Banik, B.P., dan Das, P.D., 2010. Comparison of Financial Performance of State Owned Commercial Banks: a Case Study of Bangladesh (hal. 427-428), India Online ISSN: 2319-7064, International Journal of Science and Research (IJSR).

Chandra, R, 2013. Analisis Pengaruh Capital Adequacy Ratio, Operational Efficiency, Non Performing Loan, dan Loan to Deposit Ratio Terhadap Return On Asset Pada Bank BUMN di Indonesia (hal. 36-38), Vol. 6 No. 1 Januari 2013, Jurnal Telaah dan Riset Akuntansi.

Defri, 2012. Pengaruh Capital Adequacy Ratio (CAR), Likuiditas dan Efisiensi Operasional Terhadap Profitabilitas Perusahaan Perbankan Yang Terdaftar di BEI (hal. 9-13), Volume 01, Nomor 01, September 2012, Jurnal Manajemen.

Echekoba, F.N., Egbunike, C.F., dan Kasie, E.G., 2014. Determinants of Bank Profitability in Nigeria: Using CAMEL Rating Model (2001 - 2010) (hal. 48), volume 16, Issue 9.Ver. VI (Sep. 2014), PP 44-50, e-ISSN: 2278-487X, p-ISSN: 2319-7668, IOSR Journal of Business and Management (IOSR-JBM). www.iosrjournals.org.

Fatnanda, R.R., dan Aini, N, 2013. Pengaruh DPK, BOPO, CAR dan LDR Terhadap Kinerja Keuangan (ROA) (hal. 15-16): Vol 2, Students' Journal of Accounting and Bank.

http://www.unisbank.ac.id/ojs/index.php/ fe8/issue/archive.

Ghozali, I, 2009. Aplikasi Analisis Multivariate dengan Program SPSS, Semarang: Badan Penerbitan Universitas Diponegoro.

Helhel, Y, 2014. Evaluating The Performance of the Commercial Banks In Georgia (hal. 153-155), vol.5, No.22, 2014, ISSN 22221697 (Paper) ISSN 2222-2847

(Online), Research Journal of Finance and Accounting, www.iiste.org.

Indrawati dan Srimindarti, C, 2013. Pengaruh
DPK, CAR, LDR terhadap ROA yang terdaftar di BEI (hal. 10-11): Vol 2, Students' Journal of Accounting and Bank. http://www.unisbank.ac.id/ojs/index.php/ fe8/issue/archive.

Ifeacho, C dan Ngalawa, H, 2014. Performance of The South African Banking Sector Since 1994 (hal. 7-9), Vol. 30, Number 4, The Journal of Applied Business Research July/August 2014.

Karunia, C, 2013. Analisis Pengaruh Rasio Capital, Asset Quality dan Liquidity Terhadap Kinerja Keuangan Pada Sektor Perbankan Yang Terdaftar di Bursa Effek Indonesia (BEI) periode 2007-2011 (hal. 9-10), Vol. 2, No.1 (2013), Calyptra: Jurnal Ilmiah Mahasiswa Universitas Surabaya.

Lantara, I.W.N., 2012. Business and Economic Cyle, Financial Market Fluctuation, and Bank Profitability: Empirical Evidence From Indonesia (hal. 16), Social Science Research Network. http://ssrn.com/ abstract $=2396795$.

Lukitasari, Y.P., dan Kartika, A, 2015. Analisis Pengaruh Dana Pihak Ketiga, BOPO, CAR, LDR dan NPL Terhadap Kinerja Keuangan Pada Sektor Perbankan Yang Terdaftar Di Bursa Efek Indonesia (BEI) (hal. 13-14), Vol 4, No.1, 2015, Students' Journal of Accounting and Banking.

http://www.unisbank.ac.id/ojs/index.php/ fe8/article/view/3004

Liu, J, dan Pariyaprasert, W, 2011. Determinants of Bank Performance: The Application of The CAMEL Model to Banks Listed in China's Stock Exchanges From 2008 to 2011 (hal. 87-90). AU-GSB e-Journal.

Maria, A, 2015. Pengaruh CAR, BOPO, NIM, NPL, dan LDR terhadap ROA: Studi Kasus Pada 10 Bank Terbaik di Indonesia periode 2007-2011 (hal. 13-16), Vol.4, No.1, Calyptra, Jurnal Ilmiah Mahasiswa Universitas Surabaya, 2015. 
Mitasari, D.R., 2013. Pengaruh Capital Adequacy Ratio, Non Performing Loan, Loan to Deposite Ratio, Net Interest Margin dan BOPO Terhadapa Tingkat Profitabilitas Bank (Studi Pada Bank Umum Yang Terdaftar di Bursa Efek Indonesia) (hal. 1215), Vol. 2, No. 2, Semester Genap, Jurnal Ilmiah mahasiswa FEB.

Menawati, F.O., dan Indarti, MG.K., 2012. Pengaruh Jumlah Kredit, NPL, BOPO, dan Likuiditas Terhadap Profitabilitas (hal. 1214), Vol 1, No.1, 2012. Students' Journal of Accounting and Banking.

http://www.unisbank.ac.id/ojs/index.php/ fe8/article/view/706

Maheswari, K.I., dan Sudirman, I.M.SN., 2014. Pengaruh NPL Terhadap ROA Dengan Mediasi CAR dan BOPO Pada Perbankan Indonesia (hal. 5-6), e-jurnal.com.

http://www.e-jurnal.com/2014/11/pengaruh-nplterhadap-roa-dengan.html.

Musyarofatun, L.D., 2013. Analisis FaktorFaktor Yang Mempengaruhi Rentabilitas Bank Perkreditan Rakyat di Kabupaten Magelang (hal. 93-95), Accounting Analysis Journal. http://journal.unnes.ac.id/sju/ index.php/aaj

Murti, S.G.A., dan Aini, N, 2014. Pengaruh CAR, NPL, LDR, DPK, BOPO dan Size terhadap ROA (Return on Assets) Pada Bank Umum Go Public Periode 2005-2012 (hal. 13-14), Vol 3, Students' Journal of Accounting and Bank.

http://www.unisbank.ac.id/ojs/index.php/fe8/ issue/archive.

Nurmawati, A.D., dan Widati, L.W., 2012. Analisis Pengaruh CAR, NPL, BOPO,

LDR, dan NIM Terhadap Roa Pada Perusahaan Perbankan di Indonesia (hal. 10-13), Vol 1, Students' Journal of Accounting and Bank.

Narayana, I.P.G., 2011. Perputaran Kas, Loan to Deposit Ratio, Tingkat Permodalan, Leverage dan Profitabilitas Bank Perkreditan Rakyat (BPR) Se-kota Denpasar (hal. 4346), ISSN: 2302-8556: 32-48, E-Jurnal
Akuntansi Universitas Udayana 3.3 (2013).

Ngadlan dan Riadi, R.M., 2010. Pengaruh CAMEL Terhadap Size Pada Bank Yang Listing Pada Bursa Efek Indonesia (hal. 388-389), Vol.2, No.3, November 2010: 382-390. Pekbis Jurnal.

Ozili, P.K., 2015. Determinants of Bank Profitability and Basel Capital Regulation: Empirical Evidence from Nigeria (hal. 127-128), Vol.6, No.2, 2015, Research Journal of Finance and Accounting. http:// papers.ssrn.com/sol3/papers.cfm?abstract_ id $=2544647$

Olweny, T, dan Shipho, T.M., 2011. Effects of Banking Sectoral Factors on The Profitability of Commercial Banks in Kenya (hal. 21-22), Vol. 1(5) pp. 01-30, July, 2011 ISSN: 2047 - 0401, Economics and Finance Review Available online at http:// wwww.businessjournalz.org/efr.

Ongore, V.O., dan Kusa, G.B., 2013. Determinants of Financial Performance of Commercial Banks in Kenya (hal. 248250), Vol. 3, No. 1, pp.237-252. ISSN: 2146-4138. International Journal of Economics and Financial Issues 2013. www.econjournals.com.

Putranto, A, Herwany, A, dan Sumirat, E, 2012. The Determinants of Commercial Bank Profitability in Indonesia (hal. 7-8). Social Science Research Network. http://ssrn.com/ abstract $=2456092$.

Purnamasari, D, dan Hersugndo, 2013. Pengaruh Capital Adequacy Ratio (CAR), Loan To Deposit Ratio (LDR), Non Performin Loan (NPL), dan Beban Operasional Pendapatan Opersional (BOPO) Terhadap Profitabilitas (ROA) Pada Bank Perkreditan Rakyat di Kota Semarang (hal. 14-16), Vol 2, Students' Journal of Accounting and Bank. http://www.unisbank.ac.id/ojs/index. php/fe8/issue/archive.

Pamularsih, D, 2015. Pengaruh LDR, NPL, NIM, BOPO, CAR dan Suku 
Bunga Terhadap Profitabilitas Pada Sektor Perbankan Yang Terdaftar di Bursa Efek Indonesia Periode Tahun 2009-2013 (hal. 12-17), volume, ISSN: 2442-4056, Jurnal Ilmiah Mahasiswa Akuntansi Universitas Pandanaran.

Prasanjaya, A.A.Y., dan Ramantha, I.W., 2011. Analisis Pengaruh Rasio CAR, BOPO, LDR dan Ukuran Perusahaan Terhadap Profitabilitas Bank Yang Terdaftar di BEI (hal. 238-240), ISSN: 2302-8556: 230-245, E-Jurnal Akuntansi Universitas Udayana 4.1.

Porawouw, M.A., Pangemanan, S.S., dan Mekel, P.A., 2014. The Application of CAMEL Model on Banks Listed in Indonesia Stock Exchange Period 2008-2010 (hal. 198-199), Vol.2, No.1, Maret 2014, Hal. 192-200, ISSN 2303-1174. Jurnal EMBA.

Restiyana, 2010. Analisis Pengaruh CAR, NPL, BOPO, LDR, dan NIM Terhadap

Profitabilitas Perbankan (Studi Pada Bank Umum di Indonesia Periode 2006-2010. (hal. 76-79), Universitas Diponegoro Institutional Repository.

http://eprints.undip.ac.id/29393/.

Rahayu, R.Y.K.R., dan Wahyu, L.L., 2012. Pengaruh CAR, LDR dan BOPO Terhadap Kinerja Profitabilitas Pada Sektor Perbankan Yang Go Publik di Bursa Efek Indonesia Tahun 2007 - 2010 (hal. 16-18), Vol 1, Students' Journal of Accounting and Bank.

http://www.unisbank.ac.id/ojs/index.php/fe8/ issue/archive.

Siamat, D, 2004. Manajemen Lembaga Keuangan., Edisi Keempat, Lembaga Penerbit Fakultas Ekonomi UI.

Sudiyatno, B, dan Suroso, J, 2010. Analisis Pengaruh Dana Pihak Ketiga, BOPO, CAR dan LDR Terhadap Kinerja Keuangan Pada Sektor Perbankan Yang Go Public di Bursa Efek Indonesia (BEI) (Periode 2005-2008) (hal. 131-134), Vol. 2, No.2, ISSN :19794878, Mei 2010, Hal: 125 - 137, Dinamika

\section{Keuangan dan Perbankan.}

Setiyani, E.W., dan Sudarsi, S, 2013. Pengaruh CAR, LDR, BOPO, NPL dan Size Terhadap Profitabilitas Bank (hal. 7-8), Vol 2, Students' Journal of Accounting and Bank. http://www.unisbank.ac.id/ojs/index.php/ fe8/issue/archive.

Sutaryono, P, 2013. Menggagas Indikator Efisiensi, Koran Sindo.

http://nasional.sindonews.com/ $\mathrm{read} / 719656 / 18 /$ menggagas-indikator efisiensi 1361338674

Shidieq, H.A., dan Yuliandari, W.S., SE., MM., Ak., 2012. Pengaruh loan to deposit ratio, non performing loan, good corporate governance, biaya operasional terhadap pendapatan operasional, dan capital adequacy ratio terhadap return on assets pada bank devisa yang go public periode 2010-2012 (hal. 8-9), Vol.2, No.1, April 2015, E-Proceeding of Management, Telcom University.

Sudirman, I.M.S.N.S., 2011. Influence of Macro Economic Factors, Banking Industry Factor, and Banking Spesific Factors on Banking Profitability in Indonesia: Panel Data Analysis (hal. 12-13), Social Science Research Network.

http://papers.ssrn.com/so13/Papers. cfm?abstract_id=2492528.

Sukarno, K.W., dan Syaichu, M, 2006. Analisis Faktor-Faktor Yang Mempengaruhi Kinerja Bank Umum di Indonesia (hal. 53-56), Volume 3, Nomor 2, Juli, Tahun 2006, Jurnal Studi Manajemen dan Organisasi. http://ejournal.undip.ac.id/index.php/smo.

Setiawan, L, 2015. Pengaruh Rasio CAMEL Terhadap Kinerja Keuangan Perbankan Yang Diukur Dengan Return on Assets (Studi Kasus Pada Perusahaan Perbankan Yang Terdaftar di BEI Tahun 20092013) (hal. 18-24), volume 1, No. 1, Februari 2015, ISSN: 2442-4056, Jurnal Ilmiah Mahasiswa Akuntansi Universitas Pandanaran. 
http://jurnal.unpand.ac.id/index.php/AKS/ article/view/212.

Tan Sau Eng, 2013. Pengaruh NIM, BOPO, LDR, NPL dan CAR Terhadap ROA

Bank Internasional dan Bank Nasional Go Public Periode 2007 - 2011 (hal. 162-164), Vol. 1 No.3 Juli - September 2013 ISSN: 2338 123X, Jurnal Dinamika Manajemen.

Widati, L.W., 2012. Analisis Pengaruh CAMEL Terhadap Kinerja Perusahaan Perbankan Yang Go Publik (hal. 9-10), Vol. 1, No. 2, Nopember 2012, ISSN: 1979-4878, Dinamika Akuntansi, Keuangan dan Perbankan. 